\title{
The results of spring monitoring on the status of geese populations in 2011-2018 in the North Kazakhstan Region
}

\author{
Ivan ZubaN`*, Vladimir Vilkov, Mikhail KalashniKov, \\ Konstantin ZHADAN \& Anar BissENEVA
}

Received: March 27, 2020 - Revised: May 31, 2020 -Accepted: June 05, 2020

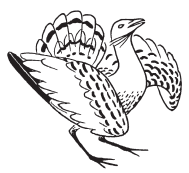

Zuban', I., Vilkov, V., Kalashnikov, M., Zhadan, K. \& Bisseneva, A. 2020. The results of spring monitoring on the status of geese populations in the North Kazakhstan Region during 20112018. - Ornis Hungarica 2020(1): 28-48. DOI: 10.2478/orhu-2020-0003

goose species at one of the largest stopover sites in Northern Kazakhstan during the springs of 2011-2018. Comparative analysis of the phenological phases at the beginning and end of migration over a 50-year period is conducted and changes in timing of migration for the studied groups are established. Data on the number of flocks at various stages of the migration process are presented. Authors revealed characteristics of the distribution of birds in the directions of migration through the region associated with the presence of various migration strategies. Based on the distribution and number of geese in the region for rest and feeding, key zones with characteristics of their natural and anthropogenic state were identified. It has been established that water bodies and large areas have optimal conditions for rest and replenishment of energy reserves for the birds.

Keywords: geese, brants, features of migrations, migration stops, numbers

Összefoglalás A cikk egy Észak-Kazahsztánban végzett monitoring vizsgálat eredményeit mutatja be, amelyben lúdfajok populációdinamikájának alakulását követték nyomon 2011-2018 között, a tavaszi időszakban az egyik legnagyobb kiterjedésủ élöhelyen. Összehasonlító elemzést is végeztek egy 50 éves időszakon át, hogy kimutassák a vonulás kezdeti és végső időpontját és az ezekben bekövetkezett változásokat a vizsgált csoportok esetén. A cikk taglalja az állományok számának alakulását is a vonulás különböző fázisaiban. A szerzők feltárták a madarak egyes vonulási irányok közötti megoszlásának sajátosságait a különböző vonulási stratégiákkal összefüggésben. A pihenő- és táplálkozóhelyként is használt vizsgálati régióban a ludak számán és eloszlásán alapulva azonosították a kulcsfontosságú területeket, valamint rögzítették ezek természetességi állapotát, az esetleges antropogén jelleget is beleértve. Megállapították, hogy a víztesteken és a nagy kiterjedésủ területeken fennálló környezeti feltételek optimálisak a madarak számára mind a pihenéshez, mind a táplálkozáshoz.

Kulcsszavak: ludak, Branta, vonulási jellemzök, pihenőhelyek, egyedszámok

Department of Biology, M. Kozybayev North Kazakhstan State University, 86 Pushkin Str., Petropavlovsk, 150000, Kazakhstan, e-mail: zuban.nksu@list.ru,zuban_ia@mail.ru

*corresponding author

\section{Introduction}

The territory of the forest-steppe zone of Kazakhstan is characterized by the presence of a large number of water bodies in various quality (Filonec 1974), which creates favorable conditions as habitat and migratory stops for birds in the wetland complex (Cresswell et al. 1999, Yerokhov 2006, 2013). 
A century ago, it was the richest region of Eurasia regarding the number of geese and ducks (Yanushevich \& Zolotareva 1947). Every year, hundreds of thousands of eggs of representatives of these groups were harvested here, as well as thousands of molting and migrating birds were hunted (Yanushevich 1940). At the beginning of the $19^{\text {th }}$ century, the economic development of the territory, associated with an increase in the population, plowing of virgin and fallow lands and excessive hunting, caused a significant reduction in the number of breeding and migratory birds. According to Isakov (1969) waterfowl resources decreased by 20 times at the middle of the $20^{\text {th }}$ century in the south of Western Siberia. Studies conducted in the forest-steppe of Kazakhstan in 1986-1988 confirmed the continuation of this process (Vilkov 1989).

Considering that the reduction in the number of waterfowl continues to the present (Rozenfeld et al. 2016, Cuthbert et al. 2018) and the fact that the North Kazakhstan region is an area through which significant flocks of geese migrate to the north in spring (Lorentsen et al. 1998, Vilkov 2011, Cranswick et al. 2012, Zuban' \& Vilkov 2015, R. Cuthbert et al. 2017, Vilkov et al. 2017), the study of their distribution in the region including dynamics of abundance in the long-term will allow us to answer many questions.

The hypothesis, that the authors adhered to when conducting the research, was that the species composition, abundance, phenology and distribution of geese over the territory depend on the conditions of a particular year, but the main stopping places remain constant, that is favorable for carrying out protective measures. During the monitoring work carried out by us in the period 2011-2018, a number of new key migration sites were identified that are important for geese. In this paper we discuss the current condition of such sites, as well as their role in preserving biological diversity.

\section{Methods}

This section summarizes the materials obtained by the authors during many years of field research on the migration of geese in the North Kazakhstan region (hereafter NKR). During the field works, authors researched almost the entire forest-steppe part of the NKR: the total length of the routes was more than 10 thousand $\mathrm{km}$, more than 320 lakes, swamps and temporary water bodies on grain fields (meltwater) were examined (Figure 1).

\section{Determination of species composition and population assessment}

Water bodies were examined using direct observations, where all birds were identified to a species level and counted. In order to estimate the number and determine the species composition of migrating flocks of geese in the spring, authors used the method set out in the "Instructions for field monitoring of the Lesser White-fronted Goose" (Tolvanen et al. 1999, Cuthbert \& Aarvak 2017). In general, the methodology included determining the total number of geese departing from the lakes in the early morning and evening hours at the places of feeding, by counting them directly. The following optical instruments were used for counting: binoculars Bushnell (magnification $10 \times 50$ ) and telescopes Viking (magnification $200 \times 80)$. 


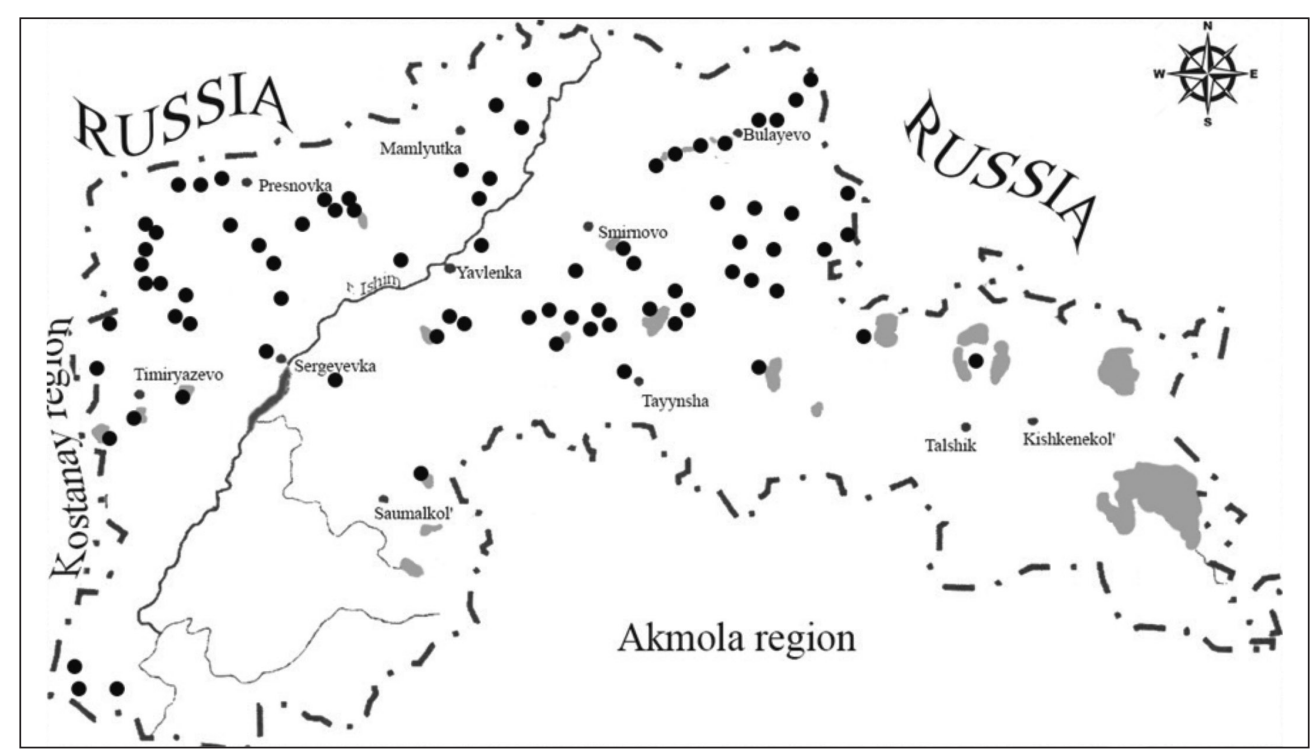

Figure 1. Map of the main surveyed lakes

1. ábra A vizsgált fö tavak térképe

The species composition of birds, in case of insufficient visibility in the morning, was clarified by identifying birds in flocks returning to the lakes from their feeding places in the middle of the day. In addition to the determination of the species, authors widely used photographing of flying flocks, with further detailed analysis of photographs, which made it possible to avoid errors in the identification of birds (Rozenfeld et al. 2016). Since photographing can only be done during daylight hours, samples were taken throughout the day from different parts of the cluster, both on the feeding fields and on daytime rest areas, trying to get as many photos of birds as possible. The series of photographs were taken of different parts of the flocks, since especially the large ones have a complex structure, due to the fact that small species (Lesser White-fronted Goose Anser erythropus (Linnaeus, 1758) - hereafter LWfG - or Red-breasted Goose Branta ruficollis (Pallas, 1769) - hereafter RBG) often fly either in the center or along the periphery, forming their own flock inside the main one.

\section{Study of the migration path}

To determine the boundaries of key stops and migration terms, as well as the timing of work, authors used information on the movement of RBG marked with GSM trackers based on Gydan (2012), Taimyr (2013) and Yamal (2014) (Vangeluwe et al. 2012, Rozenfeld et al. 2016). In addition, we used data on the movements of 9 LWfG, marked with ARGOS satellite transmitters in the east of the Bolshezemelskaya tundra in 2012-2014 (Rozenfeld, personal comment), as well as available information in Internet sources on the results of satellite tracking of the White-fronted Goose Anser albifrons (Scopoli, 1769) - hereafter WfG - (www.blessgans. de) and LWfG (www.piskulka.net). To determine the timing of the start of monitoring work, we compared polling data and satellite tracking data. When analyzing the dynamics of migration, in order to avoid obtaining a biased trend, we used counting data for a 5-day period of time. 


\section{Statistical analysis}

Statistical data processing was carried out using the computer program Microsoft Excel 2010. Statistical analysis was carried out using Student's t-test.

\section{Results}

\section{Phenology of migration}

In the course of observations, we found that the spring migration of Greylag Goose Anser anser (Linnaeus, 1758) - hereafter GlG - in the territory of NKR began between the third week of March and the first week of April. Analysis of the first GlG arrival during 20092018 showed an average date of March 27. The earliest date for the appearance of single individuals in this territory was March 20-21.

During this period of the year, almost all water bodies are still covered with ice, and there is still quite a lot of snow around them, with thawed patches beginning to appear on natural elevations of the relief. Considering the timing of the arrival of the first birds in relation to the transition of daily average temperatures through $0{ }^{\circ} \mathrm{C}$ to positive, it was found that this dependence is negative $(-0.67)$, since in 2014 and 2016 the birds arrived at the studied region later than the optimal conditions were formed, and in the remaining 8 years - earlier (Figure 2).

Early arrival for Northern Kazakhstan also includes Bean Goose Anser fabalis (Latham, 1787) - hereafter $\mathrm{BN}$ - which appears during the spring migration at about the same time as

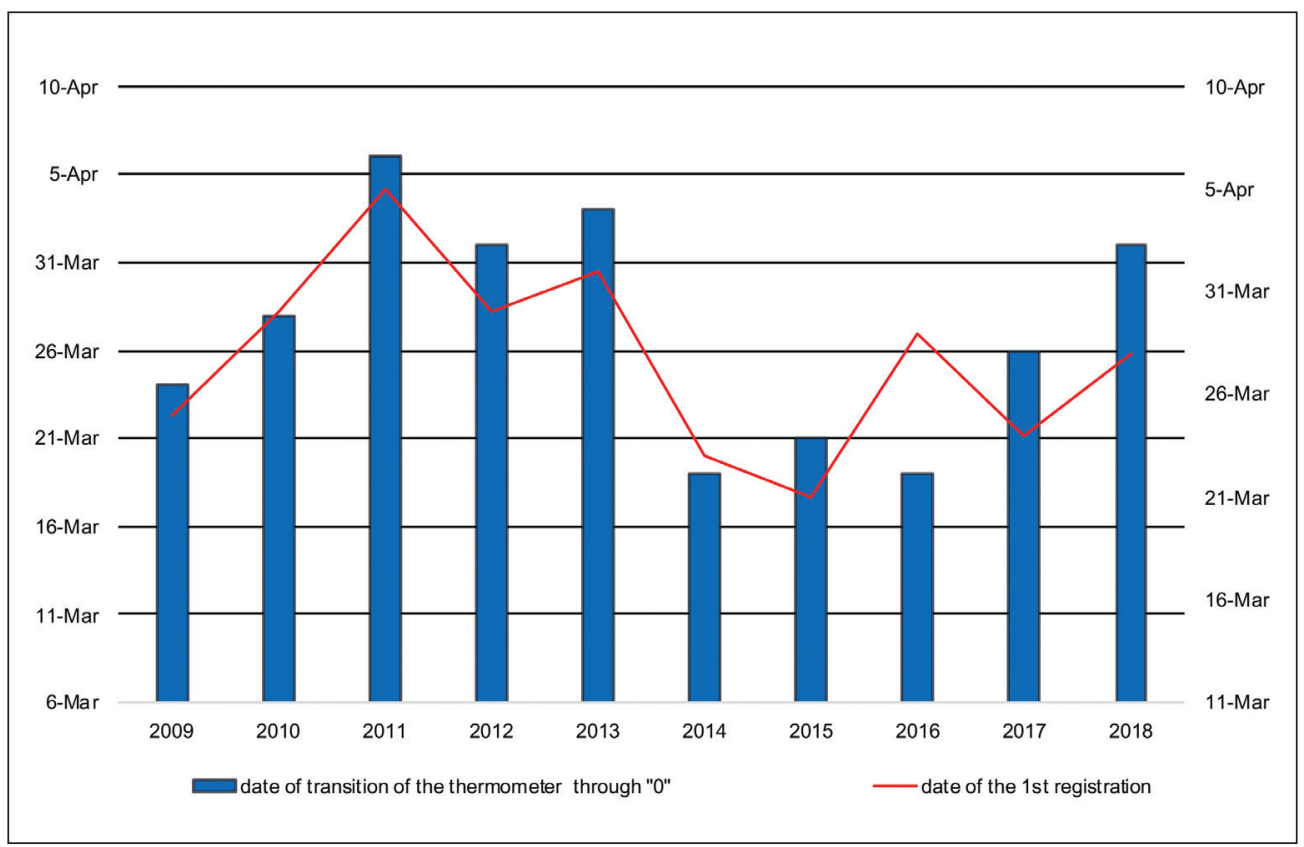

Figure 2. Dynamics of spring arrival of GIG to the NKR in 2009-2018

2. ábra A nyári lúd tavaszi érkezésének alakulása az észak-kazahsztáni régióban 2009 és 2018 között 
the GlG. 3 subspecies of Anser fabalis are reliably found in the region: A.f.fabalis, A.f. rossicus and A.f. middendorffii. The migration of the species is practically not pronounced and irregular on the territory of the North Kazakhstan region.

The first registrations of WfG in the region are timed to the beginning of the second week of April. Their arrival coincides with the period of transition of average daily temperatures through the mark of $+5-8^{\circ} \mathrm{C}$. These temperature indicators determine the partial melting of snow from the ground, the formation of temporary water bodies, the beginning of the growth of coastal vegetation, thereby ensuring unhindered access of birds to feed. Simultaneously with the appearance of WfG on the span, the mass migration of GlG begins. And from late April, an increase in the flow of migratory WfG has been observed. By May 5-10, its intensity reaches its peak, after which the numbers decline and by the $20^{\text {th }}$ of May the migration almost completely ends. Individuals or small flocks (3-30 specimens) of this species are recorded until the end of May (Table 1).

Migration of LWfG and RBG begins at approximately the same time, starting from the end of the second decade of April. At the beginning of migration, RBG fly in small flocks of 5-15 individuals, often in joint flocks with the WfG. From the end of the third decade of April, the migration rate of the RBG increases, reaching its maximum by the second decade of May. At this time, single-species flocks, forming separate clusters from 200 to 1000 birds on the periphery of flocks of WfG, are more often registered. Often migrating RBG stay on the territory of the region until the end of May, and in some years, they can be found until the first decade of June. At the same time, in the $60 \mathrm{~s}-70 \mathrm{~s}$ of the $20^{\text {th }}$ century, the RBG were not registered for the territory during the spring migration. At that time, only isolated observations of this species were known in various parts of the region in the autumn period (Drobovtsev 1976).

The analysis of the data available in the literature on the migration dates of the WfG and GlG for 1966 and our data indicates a shift in the dates of the first registration compared to earlier periods (Table 2). So, for example, according to data of Drobovtsev (1972), the average date of arrival of the first individuals of GlG in 1966-1969 accounted for 13 days earlier. A similar situation is observed for the WfG - the average dates of the first registration shifted by 9 days (Table 3). Accordingly, there was a shift in the timing of the end of the migration of the GlG, which now ends 6 days earlier. WfG migration also ends 5 days earlier.

Table 1. Phenology of the main phases of the spring migration of geese in the NKR according to observations in 2009-2018

1. táblázat A ludak főbb tavaszi vonulási fázisainak fenológiája az észak-kazahsztáni régióban tett megfigyelések szerint 2009 és 2018 között

\begin{tabular}{|c|c|c|c|c|c|c|c|c|c|}
\hline \multirow{3}{*}{ Species } & \multicolumn{9}{|c|}{ Terms of migration } \\
\hline & \multicolumn{3}{|c|}{ March } & \multicolumn{3}{|c|}{ April } & \multicolumn{3}{|c|}{ May } \\
\hline & I & II & III & I & II & III & I & II & III \\
\hline \multicolumn{10}{|l|}{ Anser anser } \\
\hline \multicolumn{10}{|l|}{ Anser fabalis } \\
\hline \multicolumn{10}{|l|}{ Anser albifrons } \\
\hline \multicolumn{10}{|l|}{ Anser erythropus } \\
\hline Branta ruficollis & & & & & & & & & \\
\hline
\end{tabular}


Table 2. Dates of spring migration of GIG on the territory of the NKR in 1966-2018

2. táblázat A nyári ludak tavaszi vonulásának időpontjai az észak-kazahsztáni régióban 1966 és 2018 között

\begin{tabular}{|l|c|c|}
\hline \multicolumn{1}{|c|}{ Research period } & 1966-1969 (Sokolov, 2005) & 2009-2018 (Our data) \\
\hline first registration & $09.04 \pm 2.65$ & $28.03 \pm 4.9$ \\
\hline last registration & $03.05 \pm 2.8$ & $27.04 \pm 3.5$ \\
\hline
\end{tabular}

Table 3. Dates of spring migration of WfG on the territory of the NKR in 1966-2018

3. táblázat A nagy lilikek tavaszi vonulásának időpontjai az észak-kazahsztáni régióban 1966 és 2018 között

\begin{tabular}{|l|c|c|}
\hline \multicolumn{1}{|c|}{ Research period } & 1966-1969 (Sokolov, 2005) & 2009-2018 (Our data) \\
\hline first registration & $20.04 \pm 6.4$ & $11.04 \pm 4.6$ \\
\hline last registration & $31.05 \pm 6.7$ & $26.05 \pm 5.9$ \\
\hline
\end{tabular}

\section{Direction of migration}

The main stream of arctic geese follows the valley of the river Ishim. A significant part of it, up to the city of Petropavlovsk, deviates in the northeast direction ( $96.8 \%$ of the total number of flocks). Then, broad fronts (about $100 \mathrm{~km}$ ) of birds fly along the floodplain of the dry river Kamyshlovka to the borders with the Omsk and Tyumen regions of the Russian Federation. The dominance of the general direction is most likely determined by clearly defined landmarks along the Kamyshlovka river bed, as well as by the location of the end points of the route, i.e. - the tundra zone in the area of the peninsulas Gydan, Taimyr and others. The total width of the migration route of geese in the spring within the region is about $470 \mathrm{~km}$. For GlG during the spring migration period, the northern direction of the migration is more characteristic (Figure 3).

The cases of emigration of geese (in the south-western direction) during the period of our observations were noted only once on May 1, 2014, and were associated with increased winds of the northern points, with gusts of up to $25 \mathrm{~m} / \mathrm{s}$ and heavy precipitation in the form of snow.

\section{Seasonal dynamics of migration}

According to the results of visual observations conducted in the spring seasons of 2011$2016,1,710,125$ individuals of geese were counted. Considering the seasonal dynamics of their migration, it was possible to detect numerous waves (Figure 4) which, by their specificity, can be combined into two groups: 1 . having two main peaks of the migration and 2 . having one peak of the migration or with a not clearly pronounced peak.

So, in 2011 and 2012 the migration took place according to the first variant, when during the spring two peaks were recorded: in the beginning and in the middle of May. In the remaining years, only one upturn was clearly visible, preceded by a mild flow of migrants. In 2014, a sharp increase in the number of migratory birds began from the end of April, and, 


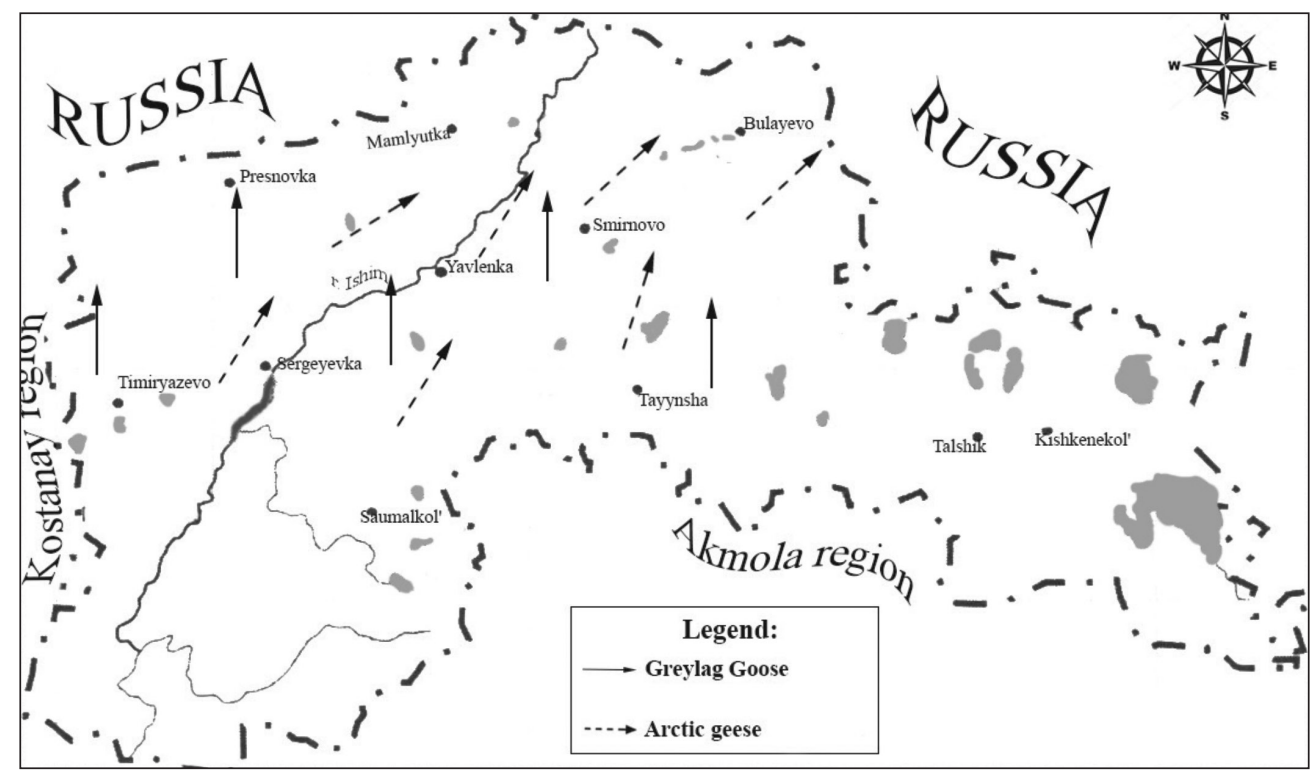

Figure 3. The main directions of spring migration of geese on the territory of NKR

3. ábra A ludak főbb tavaszi vonulási irányai az észak-kazahsztáni régióban

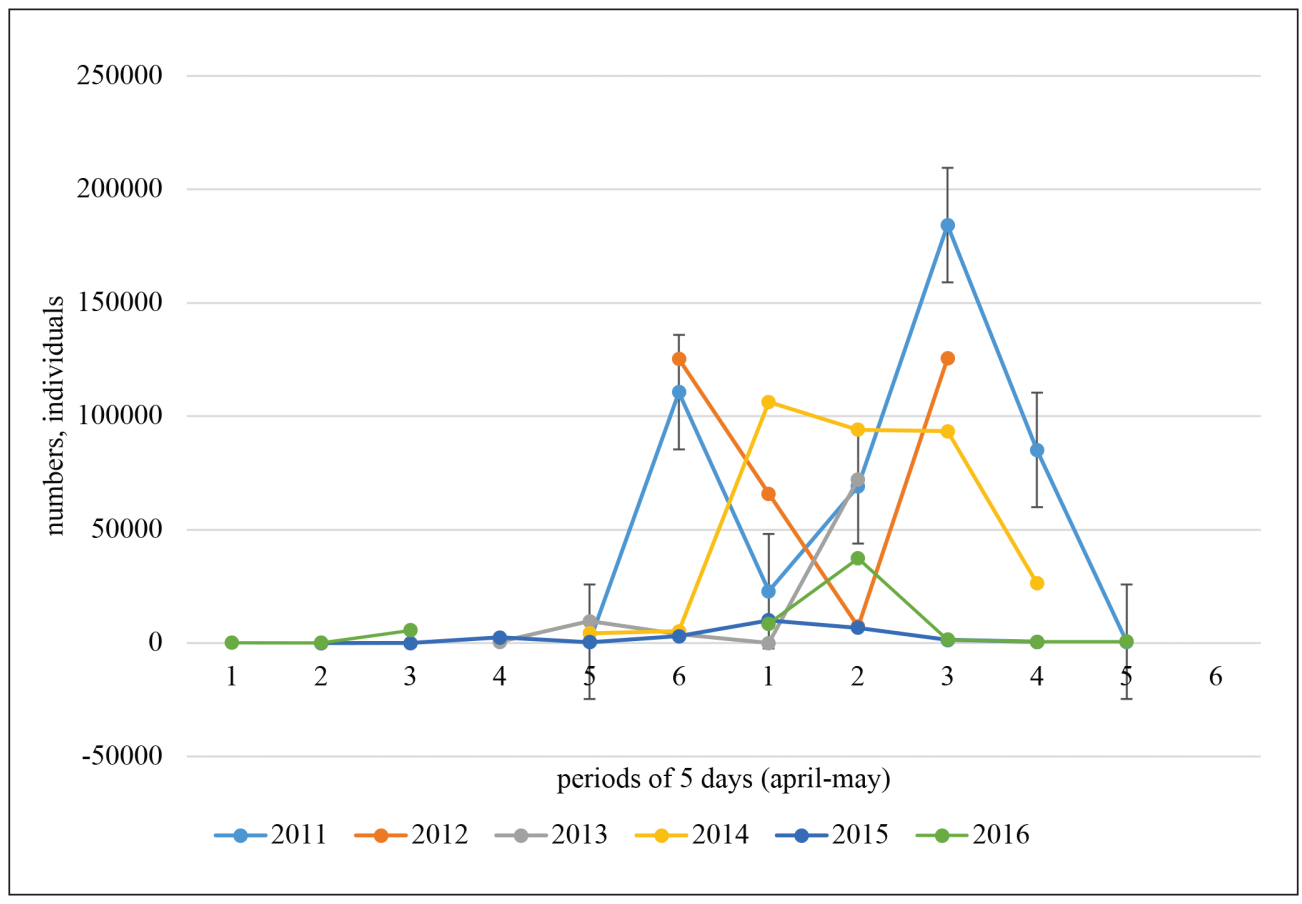

Figure 4. Seasonal dynamics of spring migration of geese in the NKR in 2011-2016

4. ábra A ludak tavaszi vonulásának dinamikája az észak-kazahsztáni régióban 2011 és 2016 között 
by the end of the first week of May, reached its maximum for the entire spring. The number of migrants decreased gradually until the third week of May, only after which the completion of migration occurred.

\section{The number of migrating birds}

Over 8 years of monitoring studies at temporary and fixed points of observation, authors counted about 2 million individuals of five species of geese (Table 4).

The most common species during the spring migration in all the years was the WfG, whose share was $94.03 \%$ of the total number of recorded geese. The second most abundant species was the RBG (5.7\%). The share of other species of geese is not large and ranges from 0.17 to $0.0004 \%$.

Analysis of the data in Table 4 shows that the maximum abundance of the studied species was observed in the water bodies of the region in the period from 2011 to 2014. The main reason for this, in our opinion, is the drought that began in 2008. Starting from 2015, the number of geese decreased 4.7 times, and in the spring of 2017 a record low number was recorded.

For the Red Book species, unstable indicators are also recorded. For example, for the RBG, the maximum number was recorded in 2011, 2014 and 2018. In the remaining years

Table 4. The number of migrating geese in the spring of 2011-2018 in NKR

4. táblázat A vonuló ludak száma a tavaszi időszakokban 2011 és 2018 között az észak-kazahsztáni régióban

\begin{tabular}{|l|c|c|c|c|c|c|c|c|}
\hline \multirow{2}{*}{ Species } & \multicolumn{8}{|c|}{ Numbers, individual } \\
\cline { 2 - 10 } & $\mathbf{2 0 1 1}$ & $\mathbf{2 0 1 2}$ & $\mathbf{2 0 1 3}$ & $\mathbf{2 0 1 4}$ & $\mathbf{2 0 1 5}$ & $\mathbf{2 0 1 6}$ & $\mathbf{2 0 1 7}$ & $\mathbf{2 0 1 8}$ \\
\hline Anser albifrons & 536,073 & 395,733 & $\mathbf{2 2 6 , 6 7 7}$ & 330,544 & 60,819 & 67,294 & 30,593 & 159,108 \\
\hline Anser erythropus & 755 & 385 & 69 & 100 & 8 & 7 & 3 & 120 \\
\hline Anser anser & 180 & 100 & 195 & 147 & 218 & 586 & 48 & 1,729 \\
\hline Anser fabalis & 1 & 1 & - & - & 6 & - & 1 & - \\
\hline Branta ruficollis & 40,951 & 26,081 & 39,57 & 12,984 & 1,764 & 4,490 & 1,153 & 18,612 \\
\hline \multicolumn{1}{|c|}{ Total } & $\mathbf{5 7 7 , 9 6 0}$ & $\mathbf{4 2 2 , 3 0 0}$ & $\mathbf{2 3 0 , 8 9 8}$ & $\mathbf{3 4 3 , 7 7 5}$ & $\mathbf{6 2 , 8 1 5}$ & $\mathbf{7 2 , 3 7 7}$ & $\mathbf{3 1 , 7 9 8}$ & $\mathbf{1 7 9 , 6 5 9}$ \\
\hline
\end{tabular}

Table 5. Aggregative behavior of geese during the spring migration on the territory of the NKR in 2011-2017

5. táblázat A ludak csapatalkotó magatartása a tavaszi vonulás során az észak-kazahsztáni régióban 2011 és 2017 között

\begin{tabular}{|l|c|c|c|c|}
\hline Numbers (individuals) & from 1 to 10 & from $\mathbf{1 1}$ to $\mathbf{5 0}$ & from $\mathbf{5 1}$ to $\mathbf{1 0 0}$ & more than $\mathbf{1 0 0}$ \\
\hline Number of flocks & $342(2.7 \%)$ & $4265(33.8 \%)$ & $6542(51.8 \%)$ & $1476(11.7 \%)$ \\
\hline Percentage (\%) & 1.5 & 14.8 & 56.5 & 27.1 \\
\hline Number of individuals & 12,580 & 122,405 & 467,099 & 224,352 \\
\hline $\begin{array}{l}\text { Average number of birds } \\
\text { in a flock }\end{array}$ & $7.2 \pm 2.1$ & $28.7 \pm 11.3$ & $71.4 \pm 14.1$ & $151.6 \pm 46.6$ \\
\hline
\end{tabular}


there was a sharp decline in numbers. The maximum number of LWfG during the spring migrations was noted in 2011, 2012 and 2018. From 2015 to 2017 its number remained stably low, i.e. 3 to 8 individuals per season.

When studying the aggregation behavior of birds (Table 5), it was found that flocks of 50 to 100 individuals accounted for $56.5 \%$ of the registered. Flocks of 11 to 50 individuals accounted for $34 \%$ of registrations ( $14.8 \%$ of the population). The proportion of flocks with more than 100 individuals was $11.7 \%$ (27.1\% of the total number of migrating birds). Most of the large clusters (73.2\%) were observed in 2011-2012.

\section{Migratory stops}

The spread of representatives in the spring period by region and specific areas of large flocks are subject to annual changes depending on the nature and extent of use of agricultural land, as well as the hydrological regime and meteorological conditions of a particular season. Using the obtained observation results, we managed to identify 9 their main localizations (Figure 5).

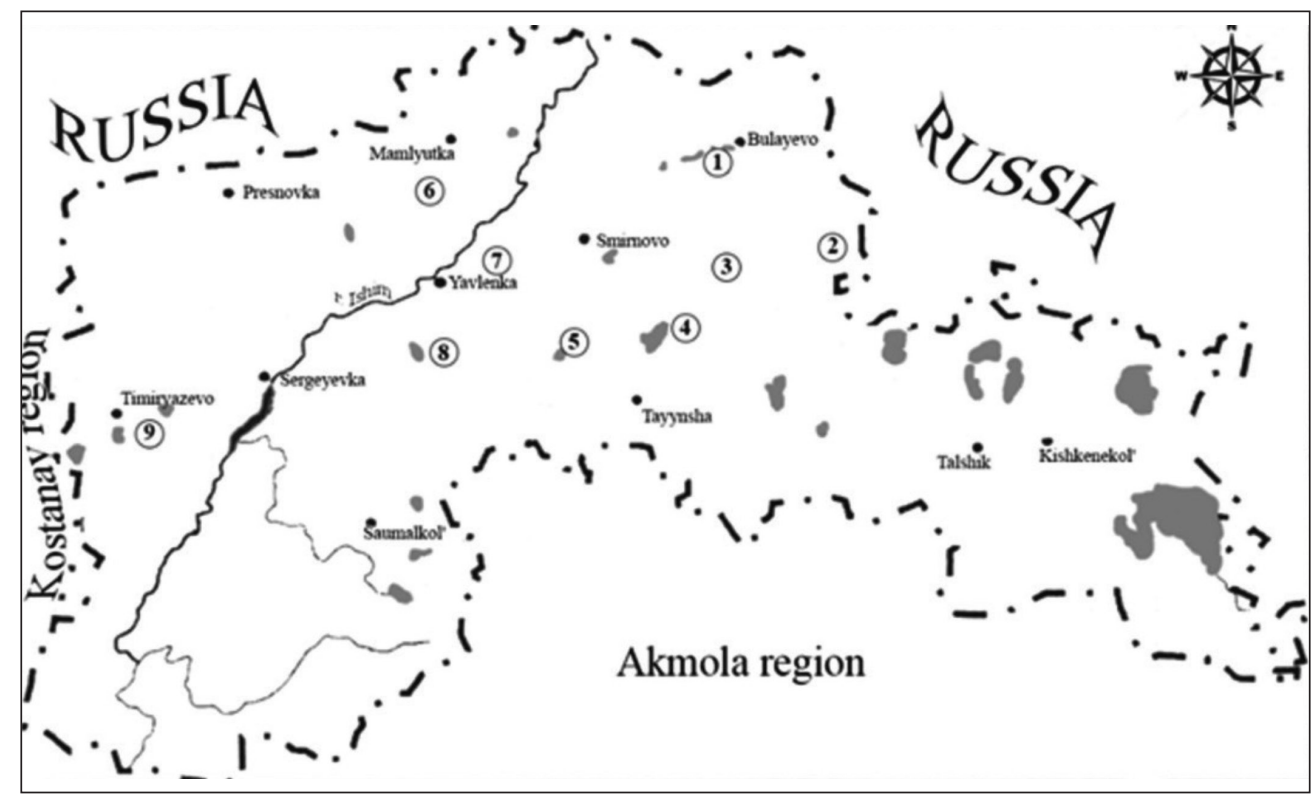

Figure 5. The main stops of geese of the genus Anser and Branta during spring migration in the territory of NKR ( 1 - Kamyshlovskiy migration zone; 2 - Vozvyshenskiy migration zone; 3 - Sovetskiy migration zone; 4 - Shaglytenizskiy migration zone; 5 - Balykty-Karasorskiy migration zone; 6 - Mengiserskiy migration zone; 7 - Karatau tract; 8 -Tarangul-Sarykolskiy migration zone; 9 - Timiryazevskiy migration zone)

5. ábra Az Anser és a Branta nemzetségbe tartozó lúdfajok föbb pihenőhelyei a tavaszi vonulás során az észak-kazahsztáni régióban ( 1 - Kamyshlovskiy vonulási zóna; 2 - Vozvyshenskiy vonulási zóna; 3 - Sovetskiy vonulási zóna; 4 - Shaglytenizskiy vonulási zóna; 5 - BalyktyKarasorskiy vonulási zóna; 6 - Mengiserskiy vonulási zóna; 7 - Karatau terület; 8 - TarangulSarykolskiy vonulási zóna; 9 - Timiryazevskiy vonulási zóna) 


\section{Kamyshlovskiy migration zone}

The zone is located in the administrative boundaries of the district named after M. Zhumabayev, in the floodplain of the former Kamyshlovka river. Its area, used by birds in different years, is about 13.5 thousand ha. The most important water bodies include a number of freshwater (Pitnoe, Polovinoye, Sukhoe swamp) and brackish (Kamyshlovo, Bolshoye Solenoye). The water area of most of them has dense vegetation (up to $70 \%$ of the area), which creates good protective conditions for birds. A significant part of the arable land is occupied by crops, which determines favorable feeding conditions for stopping birds. Among the negative factors, grazing by domestic animals along the coastline and active fishing were noted.

The intensity of use of the considered zone by birds changes throughout the entire observation period. The main limiting factor in the formation of stopover is the hydrological regime, which directly depends on the amount of precipitation during the year. So, in the spring of 2014-2016, the area of the most water bodies of the Kamyshlovskiy migration zone increased significantly due to the large amount of melting water coming from the catchment area. The typology of water bodies has changed and they have lost their significance as a migration stop. In the following years after the filling of water bodies, birds were not recorded in most areas.

The average share of Red Book species was $20.9 \pm 30 \%$ for RBG and $0.11 \pm 0.20 \%$ for LWfG (Figure 6). The average annual density of migrating geese in the main water bodies of the zone during the spring migrations is $46.01 \pm 87.4$ individuals per 100 ha.

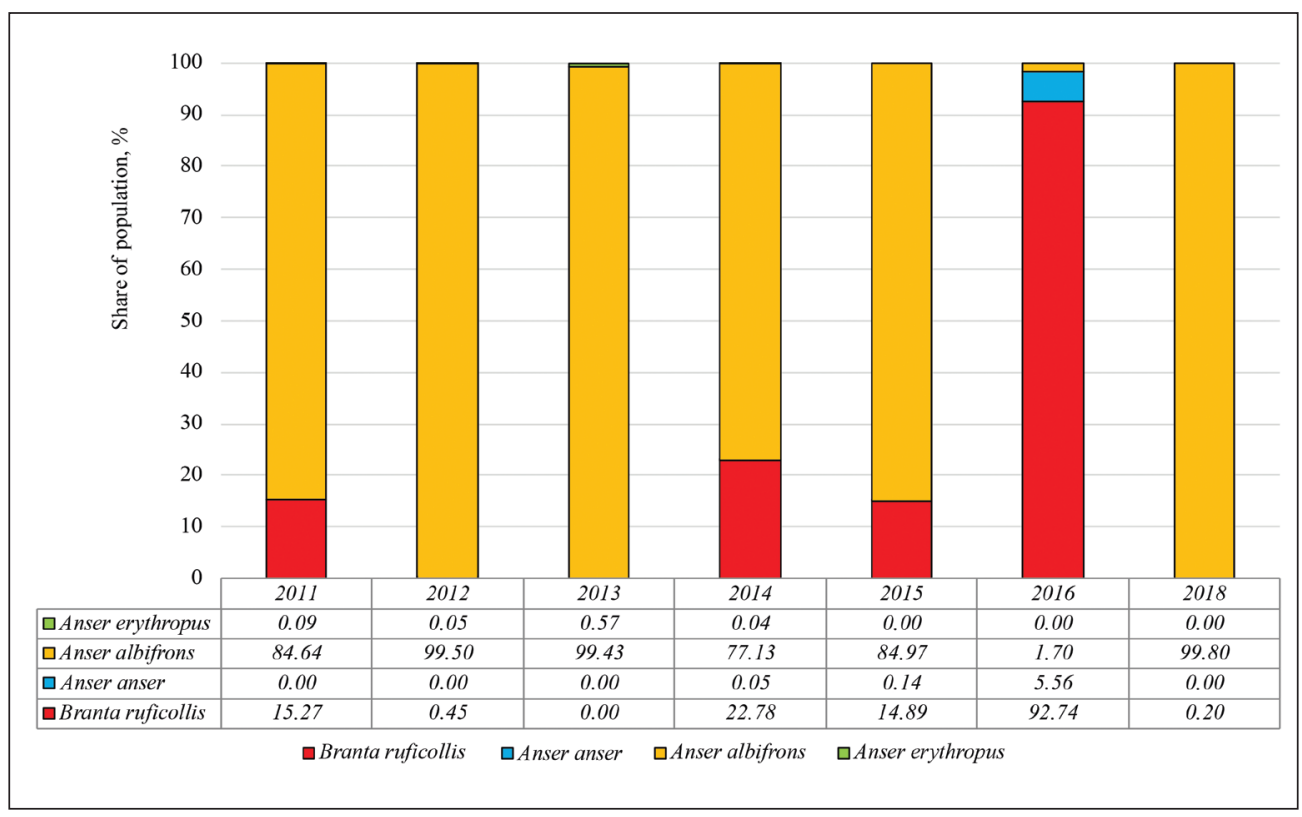

Figure 6. The ratio of the number of geese of the genus Anser and Branta on the Kamyshlovskiy migratory zone in 2011-2018

6. ábra Az Anser és a Branta nemzetségbe tartozó lúdfajok számának aránya a Kamyshlovskiy vonulási zónában 2011 és 2018 között 


\section{Vozvyshenskiy migration zone}

The territory is located in the eastern part of the region, along the border with the Russian Federation (Omsk region). In general, the migration zone covers an area of about 10.5 thousand hectares and has an unexpressed relief, with a large number of lowlands, in which temporary water bodies form in spring. Large reservoirs are represented by lakes Alva and Keltesor. The water area of the lakes has vegetation along the edges, which creates good protective conditions for the birds that stop here. Most of the land is occupied by agricultural (up to 60\%) crops (mainly wheat), which creates favorable food conditions for migratory birds. Intensive fishing plays a negative role for birds.

The intensity of the use of the zone as a stopping place for birds is unstable throughout the entire period. The main limiting factor is its hydrological regime. During the migration period, this area represents good conditions for recreation and feeding of geese. Low disturbance factor and many temporary water bodies near the feeding fields result in concentration of birds. Since 2011, 212,913 individuals of geese have been counted in this area, and the share of species from the Red Book is on average $2.3 \pm 2.66 \%$ (Figure 7).

\section{Sovetskiy migration zone}

The territory is located in the central part of the region, within two administrative districts: Akkainskiy and M. Zhumabaev. Within the zone, several independent plots can be

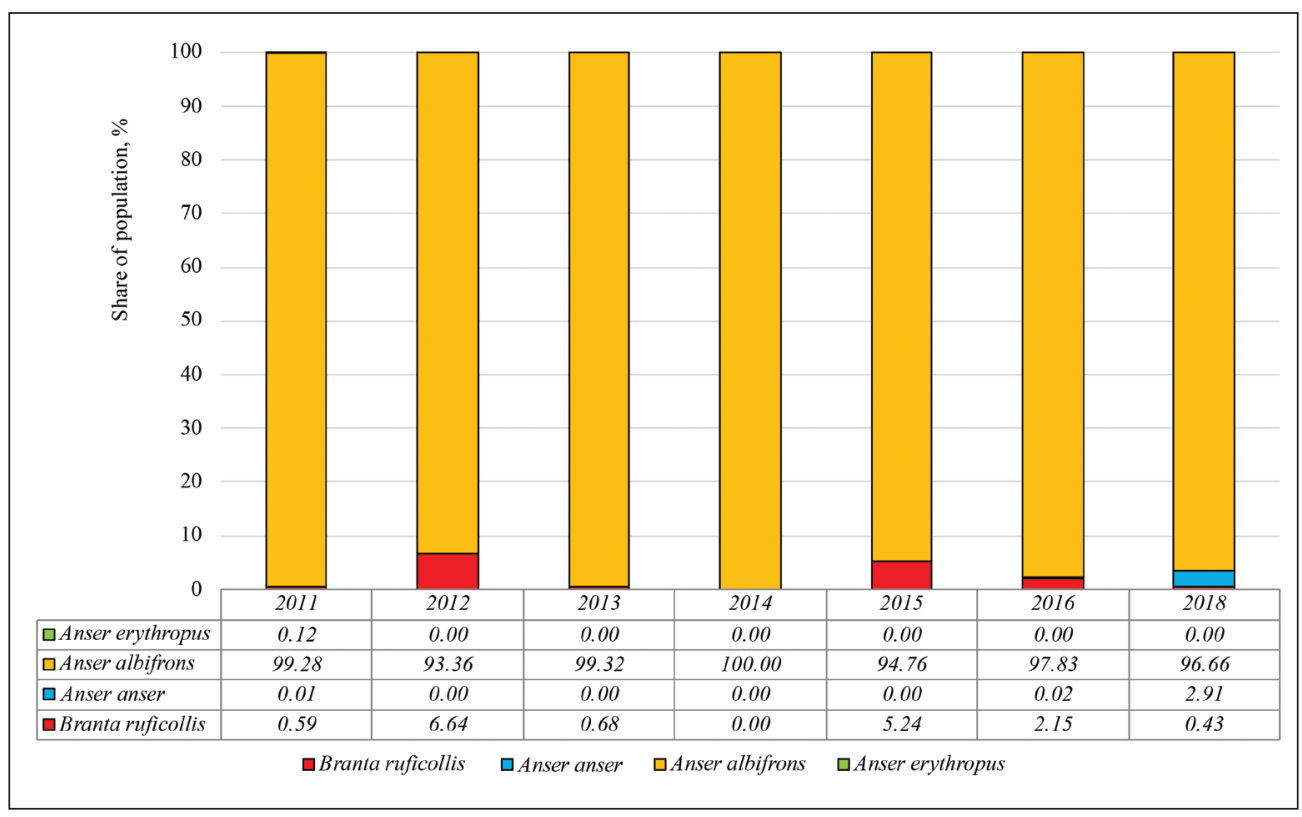

Figure 7. The ratio of the number of geese of the genus Anser and Branta on the Vozvyshenskiy migration zone in 2011-2018

7.ábra Az Anser és a Branta nemzetségbe tartozó lúdfajok számának aránya a Vozvyshenskiy vonulási zónában 2011 és 2018 között 
distinguished, in which the bulk of the birds are concentrated: 1) Letovka (former sovkhoz "Maybalykskiy"); 2) lake Karabul; 3) Kotovsko-Sovetskiy zone, discovered and investigated in the spring of 2018. Most likely, the last site was used by birds for more than a year, but due to the high waterlogging of the territory in spring and the lack of roads, it was not possible to visit it in previous years. In general, the migration zone covers an area of about 120 thousand hectares and has an unexpressed relief, with a large number of lowlands filled with water. In wet years, the territory is difficult for road transport, which increases its importance as a key stop. In addition to lowlands and marshes, there are more than 20 small and large lakes, mostly freshwater ones, which are used by birds for overnight stay. The territory is used in agricultural production (about 70\%), and is sown with grain crops. Livestock is underdeveloped. Settlements are small; therefore, the degree of influence of the human population on birds during the spring migration is minimal.

In total, 159,834 individuals of geese, including 17,336 individuals (10.8\%) of the Red Book species, were counted in this area. The total average annual density was $58.8 \pm 81.3$ individuals per 100 ha (Figure 8).

\section{Shaglytenizskiy migration zone}

The zone is located in the central part of the region, within 2 administrative districts: Akkayinsky and Tayinshinsky. The total area is about 120 thousand hectares. The zone is located between 2 waterbodies: in the West - lake Shaglyteniz, and in the East - lake Tayinsha. The

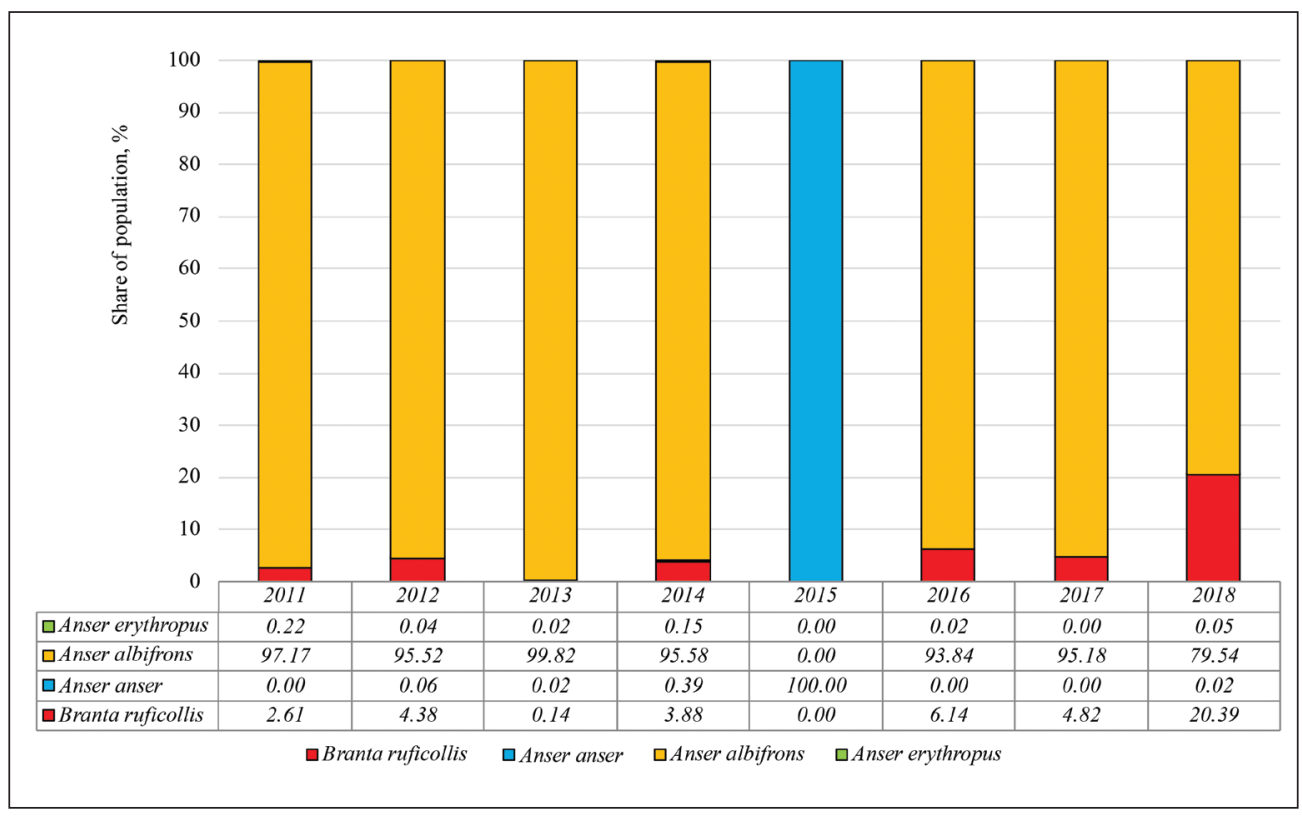

Figure 8. The ratio of the number of geese of the genus Anser and Branta on the Sovetskiy migration zone in 2011-2018

8. ábra Az Anser és a Branta nemzetségbe tartozó lúdfajok számának aránya a Sovetskiy vonulási zónában 2011 és 2018 között 
lakes are freshwater; along the perimeter are thickets that create a natural protective barrier for birds. The rest of the territory has an unexpressed relief surface with lowlands, which in spring form a network of shallow temporary water bodies. A significant part of the territory $(55-60 \%)$ is used for agricultural purposes and is occupied by grain crops, which determines favorable feeding conditions for stopping birds.

The intensity of using the migratory zone as a stopover is unstable throughout the entire observation period. In years with little snowfall, there are no spring temporary water bodies in the fields, which determine the concentration of migratory birds on key lakes. This is also favored by an increase in surface vegetation up to $60-80 \%$. As the lakes fill, their depth increases, thickets disappear, and accordingly, a decrease in the number of stopping birds is noted. During the years of low water level (2011-2012), 16387 and 71304 individuals of 4 species of geese, respectively, were counted here. Density was 9,583 individuals per 100 ha in 2011 and very high - 41,698 individuals per 100 ha in 2012 (Figure 9). As the lake is filled, thickets of surface vegetation disappear almost completely, the water depth increases almost 2 times, reaching $3 \mathrm{~m}$. For this reason, the water body ceases to play the role of a key stopping area.

\section{Balykty-Karasorskiy migration zone}

This zone is located in the central part of the region, in the administrative boundaries of two districts - Akkayinskiy and Tayinshinskiy, covering about 132 thousand hectares. The main landscapes are represented by steppe areas, most of which are plowed up and used for

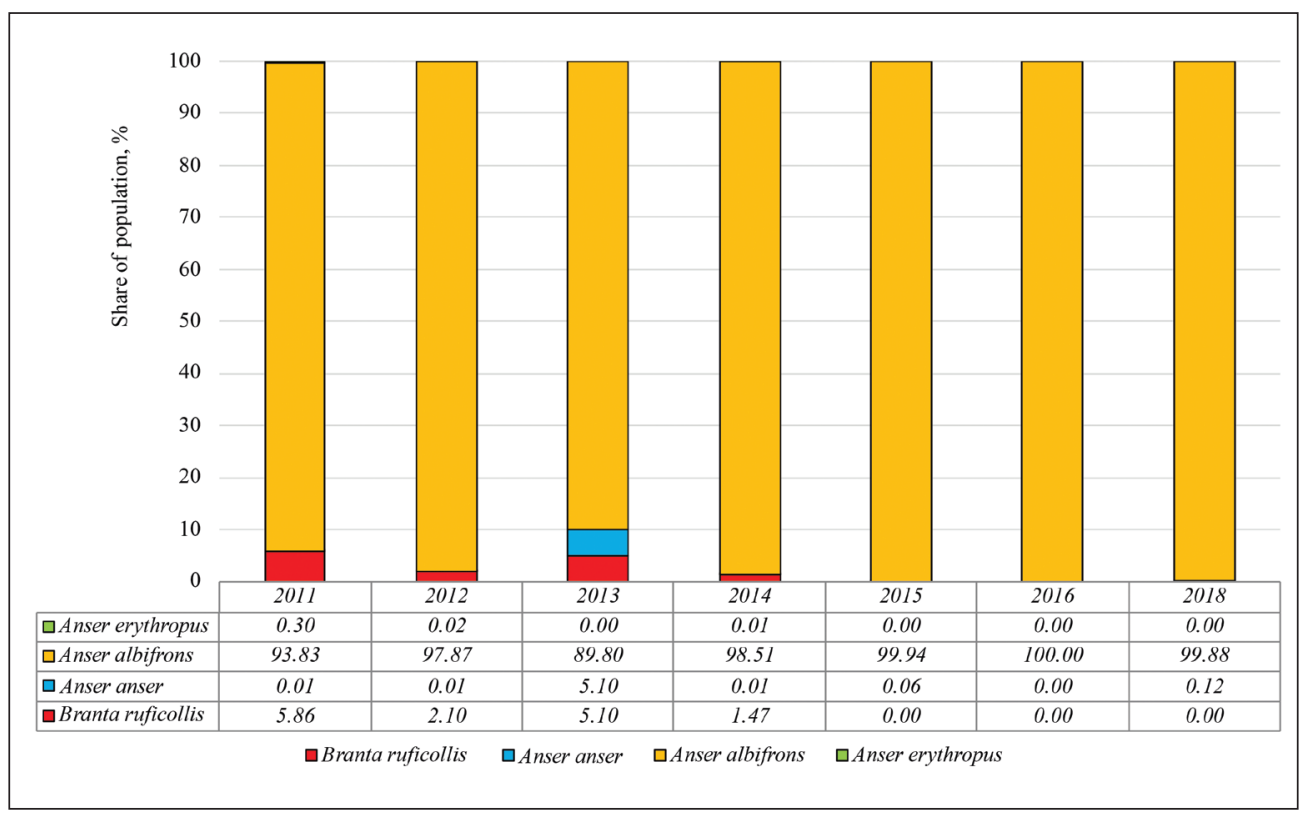

Figure 9. The ratio of the number of geese of the genus Anser and Branta on the Shaglytenizskiy migration zone in 2011-2018

9. ábra Az Anser és a Branta nemzetségbe tartozó lúdfajok számának aránya a Shaglytenizskiy vonulási zónában 2011 és 2018 között 
the cultivation of crops. Large water bodies are presented by freshwater (Uzynkol, Balykty, Zhylandy) and brackish (Kumdykol, Malye Balykty, Karasor) lakes. All the main water bodies of the zone have a strip of shallow water, and overgrown vegetation $(20-70 \%)$ in the water area. The main part of the migration zone is represented by agricultural land used for growing crops, which are a feed resource for migratory birds.

All this in a complex creates favorable conditions for stopping migratory geese in the spring, especially during the period of a general decrease in water level. In total, since the beginning of 2011, 288,500 individuals of 4 species of geese have been registered in this territory. In all the years, the WFG was the leader in numbers and its average annual share in the total aggregations of geese was $95.4 \pm 3.1 \%$, the RBG share was $4.2 \pm 2.7 \%$. The share of other species is not significant (Figure 10).

\section{Mengiserskiy migration zone}

This zone includes water bodies and the territories surrounding them, located in the northern part of the region, on the left coast of the river Ishim, within two administrative districts - Mamlyutskiy and Kyzylzharskiy. In the southern part, the boundary of the zone is Lake Mengiser, in the eastern part - the village Andreyevka, and in the northern part - the village Simaki. The area is about 430 thousand hectares.

The territory is characterized by a slightly undulating relief, the presence of small lakes and swamps. Lowlands during the spring flood are difficult to transport, which reduces the disturbance factor for birds. The key body of water is a shallow bitter-salty lake Mengiser

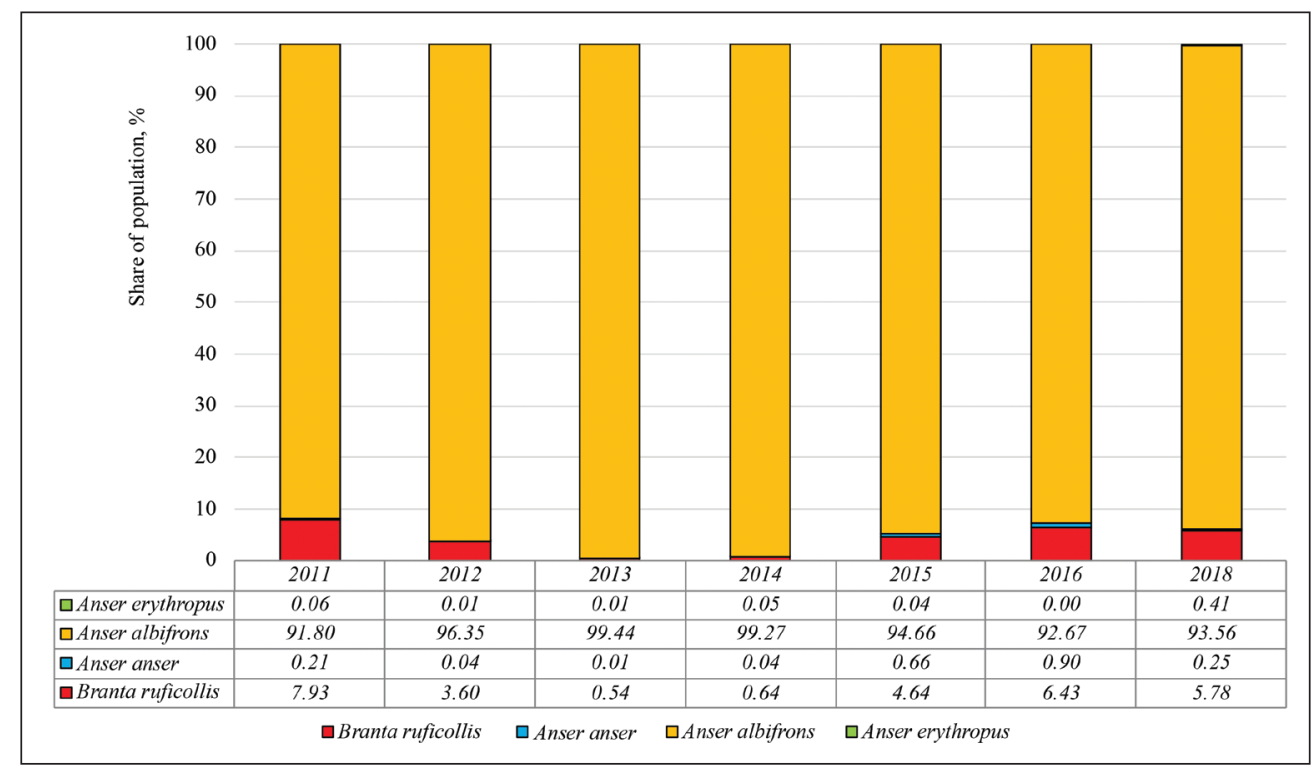

Figure 10. The ratio of the number of geese of the genus Anser and Branta on the Balykty-Karasorskiy migration zone in 2011-2018

10. ábra Az Anser és a Branta nemzetségbe tartozó lúdfajok számának aránya a Balykty-Karasorskiy vonulási zónában 2011 és 2018 között 
(4 thousand ha), with extensive shallows in the eastern part and sparse thickets of surface vegetation along the western shore. For smaller water bodies (lake Egora Andreevicha, swamp Krasnaya Shapka) the presence of sites with floating islands and humps that attract geese for overnight is characteristic. A significant part of the migration zone is used for agricultural purposes and is sown (50-55\%) with crops, which determines favorable forage conditions for stopping birds.

Totally, 20,767 individuals of 4 species of geese have been counted in the zone since 2013 . In almost all the years, the WfG was the leader in numbers. Its average annual share in the total concentrations of geese was $92.7 \pm 11.7 \%$. RBG on the second place with share $7.2 \pm 11.67 \%$. Share of other species was not significant. The average annual population density of geese in the water bodies of the considered area was $58.8 \pm 81.3$ individuals per 100 ha.

\section{Karatau tract}

Tract Karatau is located $400 \mathrm{~m}$ east of village Chirikovka of Esilskiy district and $3 \mathrm{~km}$ from the main waterway of the region, the Ishim river. The total area of land used by birds in different years, with varying degrees of intensity, is about 670 hectares. It is a network of various-sized relief depressions, filled with water, alternating with hills and islands. During years of high humidity, most of the hills and islands are flooded with water, forming a single shallow water area with areas covered by surface vegetation. A significant part of the territory $(40-50 \%)$ is used for agricultural purposes and is occupied by crops, which determines favorable feeding conditions for stopping birds. Of the negative factors, it is worth noting the close location of roads (including community significance), which creates a noisy background that causes concern in birds.

The intensity of use of the considered territory as a stopping site for birds is relatively stable throughout the entire observation period. Since 2012, the tract is a place of regular stops for geese during the spring migration. In total, for the period of studies in the spring period, 21,390 individuals of 5 species of geese were counted in this area. The average share of the Red Book species was $34.26 \pm 13.5 \%$ for RBG and $0.03 \pm 0.06 \%$ for LWfG (Figure 11). The average annual density of migratory geese in this area in spring is $416.3 \pm 332.1$ individuals per 100 ha, and the for the Red Book species is $132 \pm 93.6$ individuals per 100 ha.

\section{Tarangul-Sarykolskiy migration zone}

This zone is located in the central part of the region, within the Esilskiy district. The total area is about 5 thousand hectares. The territory is characterized by an unexpressed low relief, partially occupied by swamps, which are filled with water in spring, creating favorable conditions for stopping migratory birds. In the southern border of the zone is the lake Bolshoy Tarangul, and in the north-east the Lake Sarykol and Batpakol swamp. Extensive vegetation bands (up to 250-300 m) are located along the shallow coasts of water bodies. Agricultural activity within the zone is intense, but in the early spring, due to the erosion of roads, it decreases. A significant part of the adjacent territory (55-65\%) is sown with crops, which provides the necessary food for migratory birds. 


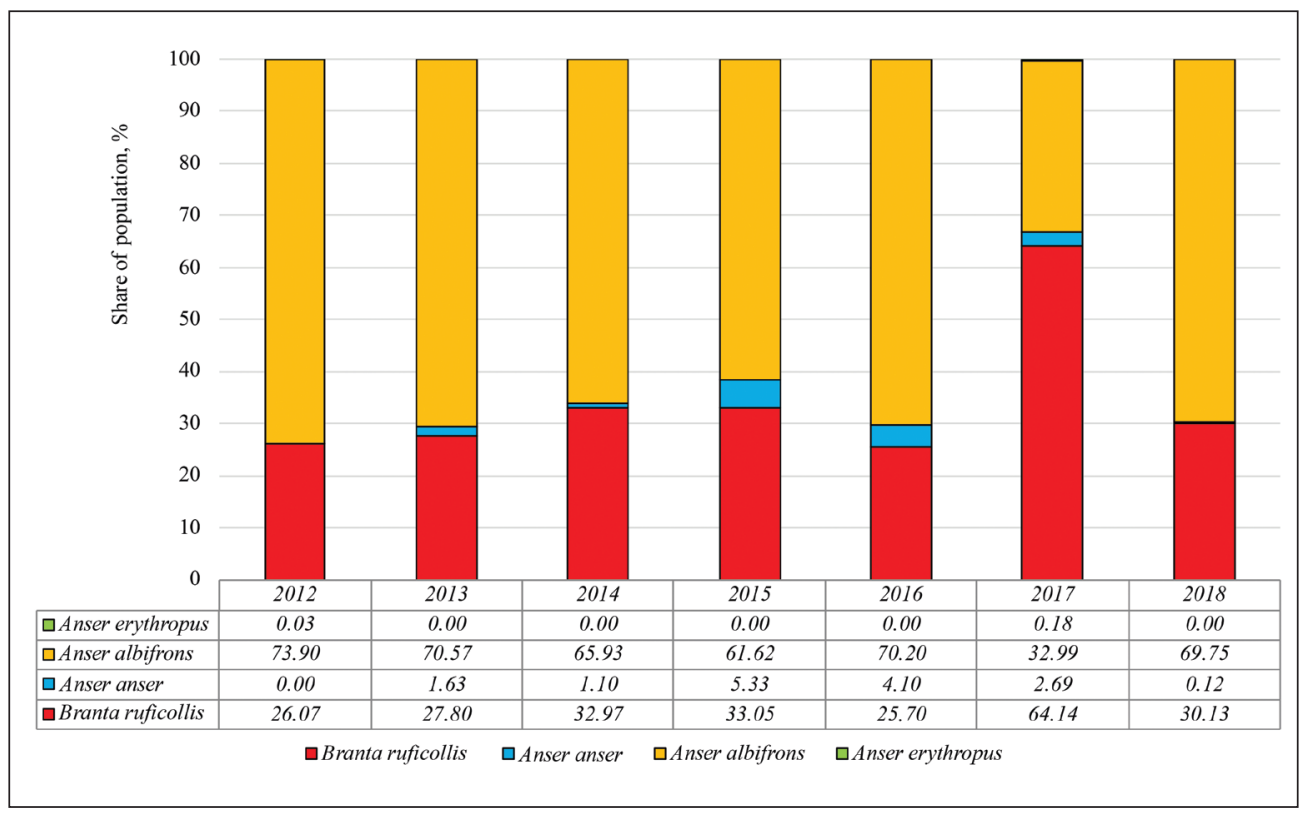

Figure 11. The ratio of the number of geese of the genus Anser and Branta on the Karatau tract in 2012-2018

11. ábra Az Anser és a Branta nemzetségbe tartozó lúdfajok számának aránya a Karatau vonulási zónában 2012 és 2018 között

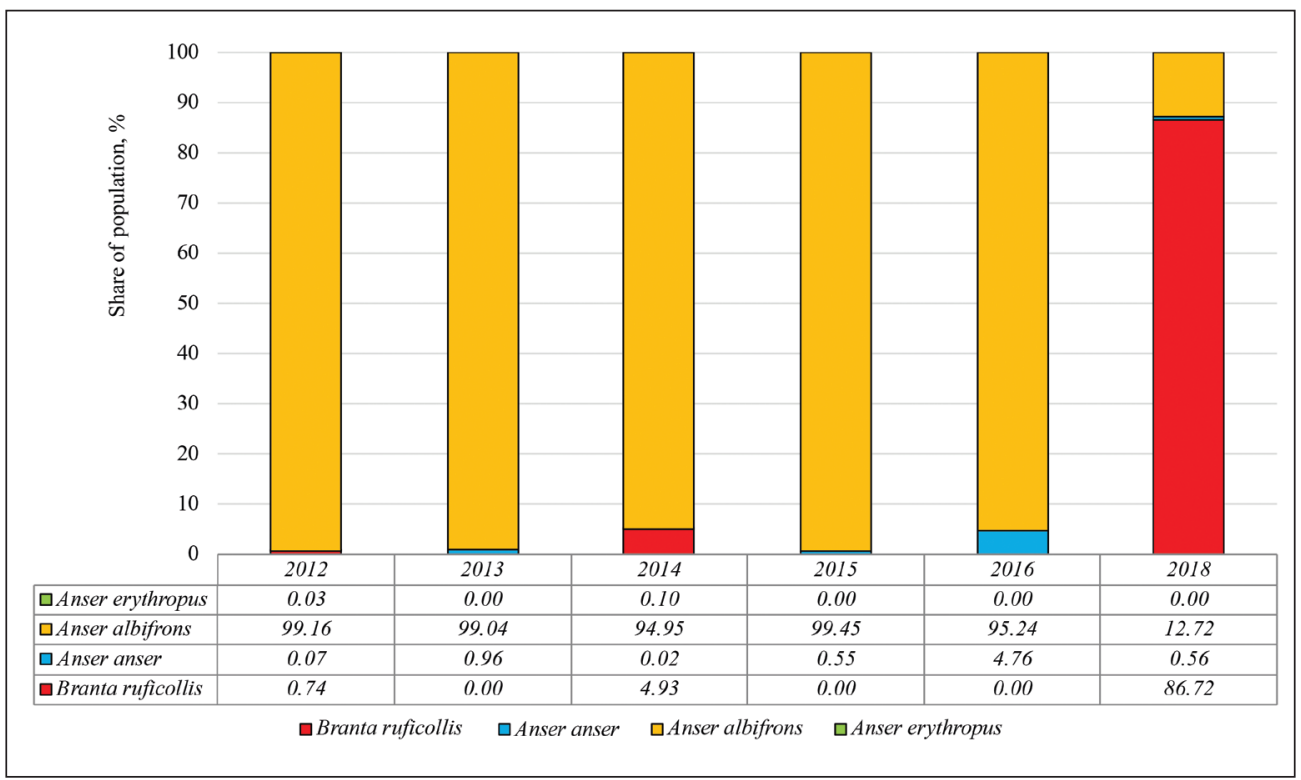

Figure 12. The ratio of the number of geese of the genus Anser and Branta on theTarangul-Sarykolskiy migration zone in 2012-2018

12. ábra Az Anser és a Branta nemzetségbe tartozó lúdfajok számának aránya a Tarangul-Sarykolskiy vonulási zónában 2012 és 2018 között 
The role of this zone as a stopping site for migrating geese in the spring is unstable and is of key importance only in dry years. In total, for the period of research in the spring period, 26,780 individuals of 4 species of geese were counted in this area. The average share of species from the Red Book was 3.2\% (Figure 12). The average annual density of migrating geese in the main water bodies of the territory during the spring migrations was $90.7 \pm 172.9$ individuals per 100 ha.

\section{Timiryazevskiy migration zone}

It is located on the southwestern outskirts of the region and borders the Kostanai region. The main terrestrial landscapes are represented by the steppe, $80-85 \%$ of which is plowed and is mainly used for sowing grain crops. In this zone, there are three large water bodies: freshwater lake Aksuat and two salt lakes Bolshoy Kak and Maliy Kak. The first lake is up to $79 \%$ overgrown with depths of up to $2 \mathrm{~m}$, the next two are shallow lakes (up to $0.7-1 \mathrm{~m}$ ) with thickets along the coastline and a wide strip of shallow water. During years of lowering the level of the water surface, the area of water areas decreases by $20-40 \%$, also the depth decreases to $0.3-0.5 \mathrm{~m}$. The main part of the territory $(40-50 \%)$ is used for agricultural purposes and is occupied by grain crops.

The role of this migratory stopping place in the life of migrating geese during the spring period is insignificant. This zone is used by birds not annually and only for a short period of time. During our work, migratory aggregations of geese were noted only in 2014 and 2018. In 2014, 17,670 individuals of 4 species of geese were recorded in this area. Species from the Red Book are registered only on 1 of 3 water bodies: lake Aksuat with about 2000 individuals of the RBG and 7 individuals of the LWfG and their share in the total aggregation was $11.8 \%$. The maximum density is noted for the WfG: 60.6 individuals per 100 ha. In 2018, 11,310 individuals of 3 species were counted in the territory. The WfG was in the first place in terms of numbers (10,939 individuals), and the proportion of Red Book species, compared to 2014 , decreased to $3.3 \%$, i.e. 371 individuals.

\section{Discussion}

Analysis of the obtained and published data shows that at the local level, interannual fluctuations in the dates of the beginning of spring migration are determined by the presence of a number of meteorological conditions. Compared with the $60 \mathrm{~s}$ and $70 \mathrm{~s}$ of the $20^{\text {th }}$ century, the timing of the appearance of the representatives of the group in transit, as well as its end, began to fall on earlier periods. A similar trend was noted in other regions (Fouquet et al. 2009). Apparently, the main reason for the general shift in the timing of migration is climate warming in the northern regions of Eurasia, forcing geese to leave their wintering places much earlier (Sokolov 2005, Pistorius et al. 2006, Bridge et al. 2010, Fox \& Walsh 2012, Fox et al. 2012, Gashev et al. 2017). According to our observations, the average arrival time of $\mathrm{GlG}$ correlates with the onset of daytime spring temperatures of $0{ }^{\circ} \mathrm{C}$. Many ornithologists (Gordienko \& Drobovtsev 1979, Belyankin \& Ilyashenko 1986, Postavnoy 1986) 
also drew attention to the regularity of the arrival of the first birds during the onset of daytime positive temperatures, although in more northern latitudes migration can begin at lower temperatures (Vengerov 1978). Along with this, there are other opinions about the reasons for the appearance of the first birds. So, according to V. Styanavichus (1983), appearance of the first birds, which include GlG, coincides with the timing of snow melt by $20-40 \%$. Obviously, this fact is due to trophic and morpho-physiological characteristics of birds (Ataev 1978). Herbivorous birds, in particular GlG, use the seeds of various plants as food resources in open areas of land.

The first registration of the remaining studied species (WfG, LWfG and RBG) in the region are timed to the beginning of the second week of April and last until the end of May. The reason for such a long migration period of WfG is the possible difference in the time of departure of birds from different wintering sites, since birds most likely first fly from Caspian wintering areas, and then from European ones, since the second migration routes are much longer (Drobovtsev 1976).

Local influences of various meteorological factors affecting the intensity of migration on different days do not determine the general course of its dynamics, since they are characterized by a one-way progressive change in any considered spring season. The dominance of the general direction is most likely determined by clearly defined landmarks and the location of the end points of the route. The main migration wave follows the Ishim River valley, deviating in a northeasterly direction. A significant change in direction was noted in a single case, which was associated with a sharp deterioration in weather conditions, increased winds of the northern points with gusts of up to $25 \mathrm{~m} / \mathrm{s}$ and heavy snowfall.

Fluctuations in the number of birds during spring migration in the region are undulating, which is most likely due to regional changes in weather conditions at stopping sites, as well as the important need for birds to combine transit flights with delays to replenish their energy reserves (Dolnik 1976). According to the results of 8 -year observations, there was a significant reduction in the number of migrants from 2011 to 2017. The maximum abundance of species and large clusters (73.2\%) were observed on the lakes of the region in 2011-2014. In our opinion, the main reason for this was the drought that began in 2008. Geese, deprived of the opportunity to use temporary water bodies and small lakes on migration routes, are forced to concentrate on larger and deeper water bodies that cover a significant part of the area. Usually, geese leave from such sites at the same time, forming large flocks (Dolnik 1976). Starting in 2015, as the water bodies filled with water, the number of birds began to decrease.

Studies have shown that the permanent migration stops of geese in the region in the spring occupy quite large areas. They include 1) grain-sown feeding sites; 2) resting sites represented by temporary water bodies on grain fields; 3 ) overnight stays located a few kilometers from the feeding places. Over the past decade, permanent stops have formed in the places where the most powerful migration flows have passed. Depending on the hydrological state of a particular territory, the ratio and number of geese inside them may vary over the years.

The instability of the use of various water bodies by birds as sites is due to the hydrological situation of the spring period in different years, the degree of anthropogenic load and disturbing factors on birds. During a period of general decline in water level, part of the coasts is represented by extensive shallows alternating with open areas with vegetation, which 
provide shelter and the water body is intensively used by birds during spring migrations. Furthermore, on the contrary, during periods of rising water levels, a change in the typology of water bodies occurs, which, in this regard, lose their importance as a place of migration stopping sites due to the redistribution of birds to more favorable places, with less concern.

The observed climate changes, while maintaining this trend in the future, can lead to both negative and positive consequences. Among the first are the instability of temperature conditions in the early spring period, which can lead (in case of snowstorms and frosts) to the migrations of birds that appeared early to the south, which are accompanied by unforeseen expenses of energy resources. At the same time, there are positive aspects for populations. In particular, since spring field work and sowing of grain and other crops in the region begin from May 5-10, the time increases during which the geese will not experience the disturbance factor in the food fields.

In the long run, the importance of the region and its individual sections for migratory birds may change, because in a market economy, more agricultural producers increase the share of cultivated areas sown by industrial crops. If this process continues, the feed value of the region will decrease, and this will lead to the redistribution of some birds outside the study area and reduce the importance of the region for geese staying here.

\section{Conclusions}

The results of a study of spring migrations of geese on the territory of Kazakhstan made it possible to clarify a number of features. Over the past 50-60 years, the timing of the appearance of representatives of the group in transit, as well as its end, began to be recorded in earlier periods. The probable cause is climate warming, the result of which are positive temperatures and melting snow observed since mid-March, and by mid-April, the snow cover has completely disappeared and a significant number of temporary water bodies have formed.

The increase in the number of birds in the region is undulating. This is most likely due to regional changes in weather conditions at the places of migration stops, as well as the important need of migrating geese to combine transit flights over areas of scarce feed resources, with delays in places rich in feed during the worst weather conditions to replenish their energy reserves.

Highlighted key migration zones are characterized by a complex of favorable factors providing optimal conditions for migratory birds, hence the highest concentration of geese beings recorded in them. One of the most important factors in the formation of temporary stopover sites for migratory birds is the presence of forage fields with grain crops. Depending on the annual state of a particular territory, the ratio and number of representatives of the considered groups within them may vary. At the local level, interannual fluctuations in the number and density of birds in individual migration zones are determined by the presence of a number of conditions: the amount of spring melt water, the area of spring temporary water bodies on grain fields, as well as the beginning of intensive agricultural work at feeding sites for geese, which determines the perturbation coefficient of migrants. 


\section{References}

Ataev, K. 1978. Migration of birds in the East Karakum. - Alma-Ata

Belyankin, A. F. \& Ilyashenko, V. V. 1986. Migratsii ptits v doline srednego techeniya r. Tomi (Zapadnaya Sibir') osen'yu 1978 goda [Migrations of birds in the valley of the middle stream of the Tom River (Western Siberia) in the autumn of 1978]. - Migrations of Birds in Asia. - Novosibirsk (in Russian)

Bridge, E. S., Kelly, J. F., Bjornen, P. E., Curry, C. M., Crawford, P. H. C. \& Paritte, J. M. 2010. Effects of nutritional condition on spring migration: Do migrants use resource availability to keep pace with a changing world? - Journal of Experimental Biology 213(14): 2424-2429. DOI: 10.1242/jeb.041277

Cranswick, P. A., Raducescu, L., Hilton, G. M. \& Petkov, N. 2012. International Single Species Action Plan for the conservation of the Red-breasted Goose (Branta ruficollis). - Bonn, AEWA

Cresswell, W., Yerokhov, S., Berezovikov, N., Mellanby, R., Bright, S., Chaves, C. J. \& McLaughlin, D. 1999. Important wetlands in northern and eastern Kazakhstan. - Wildfowl 50: 181-194.

Cuthbert, R. \& Aarvak, T. (eds.) 2017. Population estimates and survey methods for migratory goose species in Northern Kazakhstan (2016). - Bonn, UNEP/AEWA

Cuthbert, R. J., Aarvak, T., Boros, E., Eskelin, T., Fedorenko, V., Karvonen, R., Kovalenko, A., Lehikoinen, S., Petkov, N., Szilágyi, A., Tar, J., Timonen, S., Timoshenko, A., Zhadan, K. \& Zuban, I. 2018. Estimating the autumn staging abundance of migratory goose species in northern Kazakhstan. - Wildfowl 68: 44-69.

Dolnik, V. R. 1976. Theories explaining the discontinuity of migration of birds. Methods for studying the migration of birds. - Moscow, pp. 16-17.

Drobovtsev, V. I. 1972. Dinamika chislennosti i razmeshcheniya serogo gusya v Severo-Kazakhstanskoy oblasti [The dynamics of the number and stationing of Greylag Geese in the North Kazakhstan region]. - Geese in USSR, Tartu, pp. 70-78. (in Russian)

Drobovtsev, V. I. 1976. O yuzhnom puti proleta belolobykh gusey s gollandskikh zimovok [On the southern route of the migration of the White-fronted Geese from the Dutch wintering]. - Proceedings of the Meeting on Commercial Ornithology, Moscow, pp. 87-89. (in Russian)

Filonec, P. P. 1974. Ozera Severnogo, Zapadnogo i Vostochnogo Kazakhstana [Lakes of Northern, Western and Eastern Kazakhstan]. - Moscow: Gidrometeoizdat (in Russian)

Fouquet, M., Schricke, V. \& Fouque, C. 2009. Greylag Geese Anser anser depart earlier in spring: An analysis of goose migration from western France over the years 1980-2005. - Wildfowl 59: 143-151.

Fox, A. D., Boyd, H., Walsh, A. J., Stroud, D. A., Nyeland, J. \& Cromie, R. L. 2012. Earlier spring staging in Iceland amongst Greenland White-fronted Geese Anser albifrons flavirostris achieved without cost to refuelling rates. - Hydrobiologia 697(1): 103-110. DOI: 10.1007/s10750-012-1174-1

Fox, A. D. \& Walsh, A. 2012. Warming winter effects, fat store accumulation and timing of spring departure of Greenland White-fronted Geese Anser albifrons flavirostris from their winter quarters. - Hydrobiologia 697(1): 95-102. DOI: 10.1007/s10750-012-1173-2

Gashev, S. N., Aleshina, A. O., Zuban, I. A., Lupinos, M. Y., Mardonova, L. B., Mitropolskiy, M. G., Selyukov, A. G., Sorokina, N. V., Stolbov, V. A. \& Shapovalov, S. I. 2017. Holocene faunal trends in West Siberia and their causes. - Izvestiya, Atmospheric and Oceanic Physics 53(8): 791-803. DOI: 10.1134/S0001433817080059

Gordienko, N. S. \& Drobovtsev, V. I. 1979. O vesennem pereselenii i gnezdovanii Podicipedidae v severnoy chasti Kazakhstana [On the spring migration and nesting of Podicipedidae in northern Kazakhstan]. - The Pan-Soviet Conference of Young Scientists "Ecology of Bird Nesting and Methods for Studying It": 51-52. Samarkand (in Russian)

Isakov, Yu. A. 1969. O sostoyanii resursov vodoplavayushchikh ptits SSSR [On the state of the resources of waterfowl of the USSR]. - Waterfowl resources in the USSR, their reproduction and use 3: 70-78. Moscow (in Russian)

Lorentsen, S-H., Øien, I. J. \& Aarvak, T. 1998. Migration of Fennoscandian Lesser White-fronted Geese Anser erythropus mapped by satellite telemetry. - Biological Conservation 84(1): 47-52. DOI: 10.1016/S00063207(97)00088-8

Pistorius, P., Follestad, A. \& Taylor, F. 2006. Temporal changes in spring migration phenology in the Norwegian Greylag Goose Anser anser, 1971-2004. - Wildfowl 56: 23-36.

Postavnoy, G. V. 1986. Sroki sezonnykh migratsiy v Ara-Karagay [Timing of seasonal migrations in Ara-Karagai]. - Migrations of Birds in Asia, Novosibirsk, pp. 76-82. (in Russian)

Rozenfeld, S. B., Timoshenko, A. Y. \& Zuban, I. A. 2016. Monitoring sostoyaniya populyatsiy gusey I kazarok Severo-Kazakhstanskoy migratsionnoy ostanovki kak osnova dlya razrabotki mer po ikh sokhraneniyu 
[Monitoring of the state of geese and Branta populations of North Kazakhstan migration stop as a basis for the development of measures for their conservation]. - Casarca 19(1): 94-128. (in Russian)

Sokolov, L. V. 2005. Vliyaniye izmeneniya klimata na fenologiyu ptits [Impact of climate change on phenology of birds]. - Anseriformes of Northern Eurasia, St. Petersburg, pp. 238-240. (in Russian)

Styanavichyus, V. 1983. Izucheniye vliyaniya gidrometeorologicheskikh faktorov na sroki prileta ptits v rayon zapovednika Zhuvintas [Study of the influence of hydrometeorological factors on the time of arrival of birds in the area of the reserve Juvintez]. - The Second Baltic Ornithological Conference, Tallinn, pp. 202-204. (in Russian)

Tolvanen, P., Litvin, K. E. \& Lampila, P. 1999. Monitoring the autumn staging of Lesser White-fronted Geese in north-western Kazakhstan. - In: Tolvanen, P., Øien, I. J. \& Ruokolainen, K. (eds.) Fennoscandian Lesser White-fronted Goose conservation project. - Annual Report 1998, Helsinki: WWF, pp. 42-46.

Vangeluwe, D., Rozenfeld, S. B., Dmitriev, A. E. \& Bulteau, V. 2012. Preliminary results from GPS remote tracking of Red-breasted Geese (Branta ruficollis) from Gydan Peninsula (Russia) breeding grounds. - Casarca 15(2): 80-90.

Vengerov, M. P. 1978. O vesennem pereselenii lebedya-klikuna na Nizhnyuyu Ob' [On the spring migration of the Whooper Swan on the Nizhnyaya Ob']. - The Second Pan-Soviet Bird Migration Conference 2: 24-25. Alma-Ata (in Russian)

Vilkov, V. S. 1989. Biologiya vodoplavayushchikh ptits lesostepi Severnogo Kazakhstana [Biology of waterfowl of forest-steppe of North Kazakhstan]. - PhD Thesis, Moscow (in Russian)

Vilkov, V. S. 2011. Migratsii krasnozoboy kazarki Branta ruficollis v Severo-Kazakhstanskoy oblasti [Migration of Branta ruficollis in North Kazakhstan region]. - Russian Ornithological Journal 20(647): 716-725. (in Russian)

Vilkov, V. S. \& Zuban', I. A. 2017. Perspektivnyye klyuchevyye ornitologicheskiye territorii Severo-Kazakhstanskoy oblasti [Perspective key ornithological territories of North Kazakhstan region]. - Collection of Reports of the XIX. International Scientific and Practical Conference "Problems of River Basin Management during the Development of Siberia and the Arctic in the Context of Global Climate Change in the XXI. Century", Tyumen: TIU., pp. 41-45. (in Russian)

Yanushevich, A. I. 1940. Materialy po biologii vodoplavayushchey dichi Baraby [Materials on the biology of waterfowl of Baraba]. - Biological Institute of Tomsk State University (in Russian)

Yanushevich, A. I. \& Zolotareva, O. S. 1947. Vodoplavaiushchie ptitsy Baraby [Waterfowl of Baraba]. - Novosibirsk (in Russian)

Yerokhov, S. N. 2006. Past and current status of Anatidae populations in Kazakhstan. - In: Boere, G. C., Galbraith, C. A. \& Stroud, D. A. (eds.) Waterbirds Around the World. - Edinburgh, UK: The Stationery Office, pp. 269-274.

Yerokhov, S. N. 2013. The current status of the Lesser White-fronted Goose Anser erythropus in Kazakhstan: Monitoring, threats and conservation measures. - Ornis Norvegica 36: 47-51. DOI: 10.15845/on.v36i0.440

Zuban', I. A. \& Vilkov, V. S. 2015. Monitoring gusya-piskul'ki na vodoyemakh severo-kazakhstanskoy oblasti v 2014 godu [Monitoring of Lesser White-fronted Goose in the waters of North Kazakhstan region in 2014]. Bulletin of Tyumen state University. Ecology and Nature Management 1(2): 143-151. (in Russian)

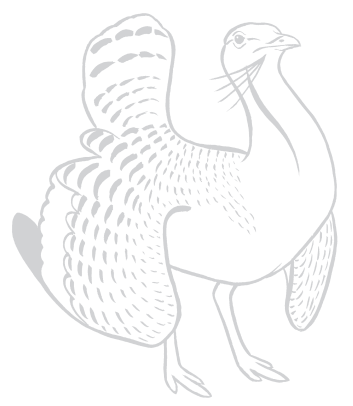

